\title{
Research
}

\section{Curriculum Differentiation's Capacity to Extend Gifted Students in Secondary Mixed-ability Science Classes}

\author{
Christine Ireland ${ }^{1}$, Terence V. Bowles ${ }^{2}$, Kimberley A. Brindle ${ }^{3} \&$ Susan Nikakis ${ }^{4}$
}

\begin{abstract}
Investigated were differences between teachers' and students' perceptions of curriculum differentiation strategies to extend highly able students in mixedability secondary science classes. Gifted underachievement and disengagement is increasing in Australian schools, potentially linked to these perception differences regarding curriculum differentiation. 161, Year 7 students, aged aproximately 11 years ( $\mathrm{n}=29$ highly able; $\mathrm{n}=132$ non-highly able), and 43 science-trained teachers were surveyed. Examined were students' and teachers' perceptions of the importance and achievability of 24 curriculum differentiation strategies, within the curriculum components of content, process, product, and environment. Significant dissimilarities occurred regarding curriculum differentiation strategies having been achieved at least once during every work unit. In particular, some strategies requiring modification of the learning environment were considered by highly able students to be significantly less frequently achieved, compared to teachers' perceptions. Implications for policy and practice were explored. Further research of curriculum differentiation that includes students' perspectives is required.
\end{abstract}

Key Words: curriculum differentiation, gifted education, highly able students, non-highly able students, mixed-ability classes

\section{Are Australian Decreasing Highly Able Students' Scores Linked to Increasing Ac- ademic Disengagement?}

Buckingham (2016) and Masters (2015) noted that over the past two decades Australia's academic assessment scores have been decreasing nationally and internationally. In particular, this included the worsening results for its highly able students (HAS). It is imperative to investigate possible reasons for these results. Academic underachievement among the gifted is a serious problem (Colangelo, Assouline, \& Gross, 2004; Emerick, 1992; Reis \& McCoach, 2000; Whitmore, 1980).

Feldhusen and Kroll (1991) found that academic underachievement for gifted children is possibly due to an inappropriate and unmotivating curriculum. They referred to boredom being a significant root cause for HAS' disengagement. Dixon (2006) stated, "If these students who have clearly demonstrated their ability to go beyond the regular curriculum ... are not given a different type of curriculum, they may languish in boredom in school and fail to develop their potential" (p. 362). Emerick (1992) explained, "reversing the underachievement pattern may mean taking a long hard

\footnotetext{
${ }^{1}$ Corresponding author, Graduate School of Education, The University of Melbourne, Australia; christine_ireland@yahoo.com, ORCID: 0000-0002-0110-9687

2 PhD, Graduate School of Education, The University of Melbourne, Australia, ORCID: 0000-0001-5785-6609

${ }^{3} \mathrm{PhD}$, Graduate School of Education, The University of Melbourne, Australia, ORCID: 0000-0002-6721-8210

${ }^{4}$ PhD, Senior Gifted Education Officer, Australia, ORCID: 0000-0001-8514-8036

(C) Talent; ISSN 2717-7122 http://talentjournal.net
} 
look at the underachiever's curriculum and classroom situation" (p. 145).

Curriculum differentiation (CD) was important to examine in this study because it is a tool that supposedly offers challenge and stimulation for HAS. It is claimed that effective classroom CD should lead to increased engagement, and to a more fully developed expression of potential (Maker, 1982; Tomlinson, 2003; Tomlinson, 2014; Van Tassel-Baska, 1986). Watters and Diezmann (2003) noted that CD, while an excellent strategy, may not be providing for the academic requirements of HAS due to lack of teachers' available time, training, and resources. Yet the fact remains that many HAS in mainstream mixed-ability classes rely entirely on their teacher differentiating the curriculum, in order to be academically extended. The achievability of this has been questioned by researchers including: Archambault, Westberg, and Brown (1993); Benny and Blonder (2016); Berger (1991); Feldhusen and Kroll (1991); Reis and McCoach (2000); and Watters and Diezmann (2003).

Classes of mixed-ability students with a wide learning range, may negatively impact HAS' achievement levels. Masters (2015) observed that many challenges are posed by the wide learning range found within Australian mixed-ability classrooms. He documented that the learning range in these classes is spread across at least five or six years. This provides a significant challenge for any teacher attempting to differentiate their curriculum. Mixed-ability classes may therefore actually contribute to HAS' increasing underachievement. Rogers (1991) stated that the reason for improved academic outcomes for students in selective classes was that more appropriate learning experiences could be provided for HAS in such a learning environment. Rogers (1998) expanded this analysis, and found that teachers were more able to target appropriate curriculum modifications when dealing with an academically homogenous group.

Mixed-ability classes, however, are the more common classroom situation in Australia. Modifying how teaching and learning happens through CD in mixed-ability classes is clearly one of the significant challenges for educators. Kulik (1993) summarised research on this point, and noted: "Benefits are larger in special classes for higher aptitude learners. Gains on standardized tests are especially large when the programs entail acceleration of instruction" (p. 9). Kanevsky (2011) indicated that the capacity for these HAS to be autonomous learners could only be fully appreciated in a modified, or specialised, classroom environment. She argued that this environment was often beyond the capacity of $\mathrm{CD}$ within mixed-ability regular classrooms. Achieving effective CD is clearly challenging.

Furthermore, some teaching approaches, it seems, make successful CD more difficult. For example: Fuller and Brown (1975); Hollingsworth (1989); Tomlinson, Tomchin, Callahan, Adams, PizzatTinnin, Cunningham and Imbeau (1994) argued that the common teacher-centred approach makes effective CD impossible. According to Gentry (2009) in most schools the burden of providing extension for HAS falls largely to the classroom teacher, rather than to other special programs. It is important then, to investigate how well CD is perceived as a successful extension approach by HAS, NHAS (non highly-able students), as well as by teachers in a mixed-ability context.

Maker's (1982) curriculum model has won support from many educators for its capacity to express the complexity of CD succinctly (Benny \& Blonder, 2016; Van Tassel-Baska, 1986; Van Tassel-Baska, 
Bass, Ries, Poland \& Avery, 1998; Watters \& Diezmann, 2000). For example, a key characteristic of this curriculum model is that teachers can use it to identify differentiation strategies across four components within their curriculum. These components include: Content (what is taught); Process (how teaching happens); Product (what the students must produce); and Environment (the learning context provided for the students). It is from this model that this study's survey is drawn. Reliability evidences for the instrument were achieved statistically.

The sample group was purposively selected. It required the identification by teachers, of a group of HAS, based on characteristics of giftedness (adapted from: Gagné, 2003; Munro, 2003; Szabos, 1989). Grouping was needed to compare teacher, HAS, and NHAS responses to the same questions about Maker's (1982) CD strategies.

Year 7 mixed-ability science classes and science teachers from three secondary schools were invited to participate. As indicated, at the researcher's request, each class was divided into 2 ability level groups (HAS and NHAS) by their science teacher. Among the total student sample, 29 were anonymously identified prior to the survey as HAS. Therefore the remaining 132 students were classified as NHAS.

In this study, asking teachers to identify HAS required them to base their decision on at least five out of twenty characteristics suggested by Gagné (2003); Munro (2003); and Szabos (1989). These characteristics were provided to the teachers on a checklist. Identifying HAS is a challenging task for any educator. It involves considering a wide range of characteristics (Munro, 2003; Szabos,1989; Winner, 1996). In addition, the potential number of these students is increased by the inclusion of creative high ability thinkers (Lassig, 2009a; Piirto, 1992). The potential sample increases again when identifying, and including, HAS who might be gifted underachievers (Reis, \& McCoach, 2000; White, Graham, \& Blaas, 2018).

Giftedness likely relates to at least one or two HAS within each class (Benny \& Blonder, 2016), or approximately $10 \%$ of the total group (Gagné, 2008). Therefore, there was an expected disproportion in the number of students in the two groups. HAS were the minor subset (29) for comparison against 132 NHAS. The HAS sample size of 29 was adequate for statistical analysis, but a larger student sample group is recommended for future research.

All participants were surveyed to ascertain the level of difference in their perceptions of the same curriculum strategies, as extension activities for HAS. Student participants were unaware that their teachers had been asked to identify a HAS group. The differences in HAS, NHAS, and teacher perceptions of the importance and achievability of specified curriculum strategies to extend HAS, were surveyed and compared.

Participants were instructed that a strategy was to be 'usually achievable' only if it were employed, or encountered, at least once per unit. As mentioned, student participants were kept unaware throughout the study that their teachers had been asked to identify a HAS group.

The Maker (1982) model described how CD can be modified to extend the important components of pace, depth, and complexity of learning for HAS. HAS find that these aspects of extension are 
crucial to prevent disengagement because of boredom (Berger, 1991; Feldhusen \& Kroll, 1991; Tomlinson, 2003). Coleman and Cross (1992) determined that gifted students were actually very frustrated by being held back by the pace and content of the traditional mainstream curriculum. Kanevsky (2011) contributed empirical evidence relevant to this study of CD for HAS, by investigating the preferences of 416 gifted Years 3-8 American students. She found that "more of the students identified as gifted wanted to learn about complex extracurricular topics and authentic, sophisticated knowledge and interconnections among ideas; to work with others some of the time; and to choose the format of the products of their learning" (p. 279).

Curriculum modification of classroom learning content for HAS requires a major review of the typical scope, and depth, of the material that is currently offered to them (Watters \& Diezmann, 2003). This may include acceleration, or being able to work with older year levels as needed. Some teachers may not be able, or willing, to provide these extension options.

Berger (1991) and Kanevsky (2011) indicated that HAS prefer to explore important real-life issues, and look for the connections between ideas. This included that HAS may also want the power to determine how their learning will be demonstrated. These learning options are indicated within this study's survey questions.

It is important, also, that teachers differentiate their teaching Process for HAS, to ensure that students are given opportunities to use higher order thinking skills. For example, HAS need to create and analyse information, rather than to simply summarise it. This teaching Process priority within $\mathrm{CD}$ fosters the generation of new knowledge, rather than simply the memorisation of old knowledge (Berger, 1991; DeHaan, 2009; Lassig, 2009a; Watters \& Diezmann, 2003).

Gentry and Gable (2001) noted several key factors in providing a differentiated curriculum for HAS, including the development of an appropriately stimulating Environment, with a high level of interest, challenge, and choice. Yang (2006) and Berger (1991) noted that the type of question asked by teachers is an important aspect of the process of differentiated teaching and learning for HAS. They stated that educators must be skilled at using questions designed to challenge, as well as to link broad areas of knowledge. Factors such as these are reflected in the survey questions used in this research.

Successful CD for HAS involves significant long-term planning, within whole-school programming. It includes elements of differentiated learning environments, within and beyond the classroom, such as a range of HAS clubs, or perhaps mentoring and pull-out extension programs for HAS. Such additions are, of course, costly of teacher time and school money. They are additions which must be embedded into the school ethos, and should be fully supported by school leadership, as well as all the stakeholders in the school's learning community (Berger, 1991).

\section{Is CD Currently Happening to Extend HAS?}

Clearly, a learning Environment appropriate for HAS improves their results. However, recent research indicated that adequate CD for HAS is not occurring (Benny \& Blonder, 2016). Archambault 
et al. (1993) stated that, left to their own devices, teachers do not modify curriculum in any significant way. Their survey of Grade 3 and 4 teachers revealed that to meet the needs of HAS, these students were often simply given independent research projects, or more advanced texts to read. Furthermore, Reis and Burns (1991) asserted that instead of challenge and high-level learning, often differentiation strategies for HAS rely heavily on 'fun' activities, such as puzzles and games, that lack both rigour and relevance. Lamb (2004) and Berger (1991) also supported that an environment that encourages high-level differentiated learning is one that includes diverse resources, and provides improved achievement results. It is prudent to note Bailey's (2010) advice that a curriculum that was enjoyable, but which failed to extend and challenge gifted children, was completely below acceptable standards.

\section{How Can Limited Teacher Training in Gifted Education be Linked to Reduced Extension for HAS?}

Teachers' responses to 'giftedness' itself is perhaps an underlying issue to consider (Geake \& Gross, 2008). They asserted that teacher attitude to giftedness is generally poor. According to Mastropieri and Scruggs (2004); Lassig (2009b); and Tomlinson and Moon (2013), a lack of appropriate teacher gifted-education training may be a significant factor in this problem.

In this study, the term 'highly able student' was used by the researcher in place of 'gifted student' because the teachers involved in the study were reluctant to label any of their students as 'gifted'. They were comfortable, instead, with the term 'highly able'. In fact, the provision of programs for HAS that are different to what is provided for all students, may be seen by some educators as elitist, or unnecessary. This problem is described by Benlow and Stanley (1996) as leading to the dumbing down of curriculum, so that schools teach all students at the same academic level, and from the same curriculum.

HAS are often interested in natural sciences, and strive to understand at an advanced level the 'rules' behind the natural world. However, in their secondary science classes, HAS might question and challenge the regular teacher's level of knowledge (Benny \& Blonder, 2016). Successful CD for high-ability science students, needs curriculum advancement of Content well beyond the confines of a regular mainstream classroom. Benny and Blonder (2016) indicated that this requires teachers with an advanced understanding of the subject, as well as access to higher levels of science study beyond the classroom. Having a very high level of science knowledge may not be the case for all teachers timetabled to pick up a junior science class. Some teachers may not know what is required to differentiate for HAS' extension, and therefore may find this is not achievable in a mixed-ability secondary classroom.

All teachers need to be aware of the wide range of resources that are available to extend HAS. These include the value of relevant local, or international, tertiary-linked extension opportunities for their HAS. Some Australian universities, such as Melbourne University, offer programmes for a limited number of high ability secondary science students.

Differentiation of a science curriculum to extend HAS does not mean simply learning a series of facts, formulae, and experiment procedures. Hockett (2009) suggested that there is such a thing as 
'curriculum fortitude'. This is when topics and content have significance and sustainability. Strong topics, and content, develop ideas in depth, and connect areas across the disciplines. The topics found within a competent, differentiated, science curriculum should also be linked to the real world. Science learning must be relevant to students' world- investigations, as well as to their deeper understanding of the discipline itself.

A differentiated curriculum clearly needs to be pitched at a more challenging level. It should provide ability entry points beyond the chronological age level of HAS. For example, appropriate learning for HAS provides challenge and utilises higher order thinking skills, rather than learning more of the same (Hockett, 2009). The questions in the Student Survey, (Appendix A) and the characteristics in the Highly Able Student Selection Checklist (Appendix B) reflect these qualities. The HAS selection criteria involved observable cognitive skills. These included speed of learning and ability to solve complex problems. In addition, the Survey included broader elements such as: the capacity to make unusual links between ideas; manipulate abstract ideas; and identify important new concepts.

Clearly, CD involving an appropriate level of complexity and advancement, requires appropriate resources, as well as relevant teacher training. However, teachers without significant gifted education methodology and whole-school support, may find it confronting and challenging to provide such enrichment or acceleration options (Colangelo, Assouline \& Gross, 2004). Gifted education guidance for all teachers is important as some of the most significant aspects of good education for HAS, and for all students, can be found within that training (Davis \& Rimm, 2004).

\section{How This Study Adds to Previous Research}

There is little research that examines and compares teacher and student perceptions of CD strategies as tools to extend HAS. It was considered beyond the scope of this paper to compare specific survey questions in detail. However, teachers' perceptions compared to students' perceptions, need to be examined regarding the provision of CD for HAS. Kanevsky's (2011) study, while comprehensive, lacks comparative teacher data such as provided by this current investigation. Gentry and Gable (2001) provided other tools to investigate students' perceptions. Again, no comparative teacher data was provided, nor were specific CD strategies targeted. Yoon (2009) developed useful models for evaluating student progress, showing the importance of self-regulated learning for scientifically gifted Korean middle-school students. In Yoon's (2009) study, teacher and student data regarding the use of $\mathrm{CD}$ strategies were not compared within a classroom context. Without adequate data from both the students and teachers, an accurate picture of what is happening, required, or preferred, cannot be established.

Theories on the educational needs of HAS have generally emerged from consideration of primary school models derived from the United States and other overseas data, rather than local Australian data. Evidently therefore, there is a considerable gap in CD research for HAS that investigates secondary, mixed-ability, domain-based class groups. Importantly, scores for secondary HAS are typically more at risk for underachievement, than for primary school students (Gentry \& Gable, 2001).They noted that decreases happened more predictably for some HAS, as they moved into a 
learning environment of multiple subjects and teachers. Even so, secondary school research is limited compared to the level of research completed for primary school students (Reis \& McCoach, 2000; Tomlinson, 2003).

Therefore, this research focused on determining to what extent HAS perceived they are being extended through CD strategies in a mixed-ability secondary context. It examined how similar their perceptions were, compared to those of their teachers. It sought to illuminate potential gaps in what teachers assume is happening to engage, challenge, and extend HAS. Examining CD strategies within Maker's (1982) curriculum components of Content, Process, Product, and Environment, provides a comprehensive range of strategies to consider.

\section{Method}

\section{Participants}

A sample of 204 respondents, comprised of 29 HAS, 132 NHAS from six science classes, and 43 secondary teachers, was used to address this study's research questions. The age range of the students was 11 to 13, and the age range of the teachers was 23 to 64 . The classes were of mixed gender. These data were considered to have no impact on this study, and were not discussed. The anonymity of the selected HAS and NHAS was maintained throughout the study. This quantitative study was undertaken in three Victorian metropolitan, secondary, non-selective, private and public schools, from similar socio-economic regions.

\section{Materials}

A survey was modified from a list of CD strategies offered by Maker (1982). Questions regarding the perceived importance and achievability of these strategies can be seen in Table 1. The survey instrument used a four-point Likert scale to explore: how the student and teacher participants perceived a strategy's importance to extend HAS as (1) no importance, (2) limited importance, (3) important, (4) extremely important; and a strategy's achievability was evaluated as (1) not achievable, (2) occasionally, (3) usually achievable, (4) always achievable. The participants were advised that the term 'usually achievable' indicated that it occurred at least once per unit. The 24 strategies were grouped into those that pertained to: the Content of the lessons 'what they learn'; the Process 'how they learn'; the Product 'what they are expected to do or make'; and the Environment 'the physical and invisible learning space provided' (see Appendix A)

As no previous reports of the structure of the surveys had been provided, a series of exploratory factor analyses on the 24 importance and the 24 achievability items were completed. In both instances, two, three, and four factor solutions were explored. This resulted in indeterminate and badly fitting items to factors, both conceptually and statistically. For both importance and achievability, the scree plot indicated that a single factor was preferable. Hence for both surveys, the 24 items were combined into a total importance and total achievability score. The Cronbach's (1951) alpha coefficient for the importance scale was .91, and achievability was .92.

The study employed purposive sampling to examine responses from a subset of HAS, within the 
larger student survey sample. While the survey was shown to be robust, the small sample size provided by the selected HAS is a limitation of the study, and further research is indicated.

Student and Teacher Survey, Appendix A, (adapted from Maker, 1982).

The 24 strategies were grouped into those that pertained to Maker's (1982) four curriculum components: the Content of the lessons- 'what they learn'; the Process- 'how they learn'; the Product'what they are expected to do or make'; and the Environment- 'the physical and invisible learning space provided'. This curriculum model is supported by the Research Association Australian Curriculum and Reporting Authority, (2011).

A HAS characteristics page (see Highly Able Student Selection Checklist, Appendix B) from Gagné (2003), Munro (2003), and Szabos (1989), was provided to teachers before the surveys. Each had a checklist of 20 items, listed to help identify HAS in their classes. A minimum of five characteristics was required to be ticked for a student to be considered a HAS.

\section{Procedure}

To address the research questions, the Statistical Package for the Social Sciences (SPSS) was used in order to conduct a one-way analysis of variance (ANOVA). This was considered to be the most appropriate statistical procedure for examining the research questions, as ANOVA allows the researcher to determine the effect of multiple dependent variables (Tabachnick \& Fidell, 2013).

The students' survey was phrased in the third person. The teachers completed the same surveys, except that the descriptors were phrased in the first person. For example, 'Individual Learning Plans are a good idea for students of high ability' was replaced with 'I provide individual Learning Plans for highly able students'.

Teachers responded to a third question asking them to rate how frequently they typically felt they used these strategies in their classroom to extend HAS. The Likert scale responses used in this case were: (1) hardly ever; (2) sometimes; (3) more than half the time; (4) almost always or always. These data were compared to the teachers' 'achievability' data to increase research validity.

For the students, the researcher read aloud each question, and clarified words as required. The survey was administered by the researcher in the students' class time, with their science teacher in attendance. Six science teachers of the students surveyed completed the survey, as did 37 other secondary science teachers in their own time, with the researcher. The survey took approximately 20-30 minutes to complete, including time for clarification of questions.

\section{Results}

\section{How Were Perceptions of CD's Importance Linked to HAS'P of Its Achievability?}

The data were screened for normality, linearity, homogeneity of variance, and the absence of outliers. The data were concluded to be appropriate for further statistical analyses. The student respondents were divided into two groups: one containing HAS $(n=29)$, and the other containing NHAS $(n=132)$. 
The correlations of the importance with the achievability of the CD are shown in Table 1. The relationship between these two factors is consistently positive, and more highly related for the teachers and NHAS group. The whole sample has a correlation which is relatively lower at $r=.3$. This is because the HAS saw the relationship between the importance and achievability of CD negatively related, and less correlated.

Table 1. Correlations of the Categories of Respondents

\begin{tabular}{lcccc}
\hline & \multicolumn{4}{c}{ Importance } \\
\cline { 2 - 5 } & $\begin{array}{c}\text { Whole } \\
\text { Sample } \\
(n=203)\end{array}$ & $\begin{array}{c}\text { Highly able } \\
\text { students } \\
(n=29)\end{array}$ & $\begin{array}{c}\text { Non-highly able } \\
\text { students } \\
(n=132)\end{array}$ & $\begin{array}{c}\text { Teacher } \\
(n=43)\end{array}$ \\
\hline Achievability & .30 & -.25 & .53 & .54 \\
\hline
\end{tabular}

Note. All correlations significant to .001, 2-tailed

The means, standard deviations, and $\mathrm{F}$ ratios for each category of student respondent are presented in Table 2.

Table 2. Student Ratings of the Importance and Achievability of Curriculum Differentiation

\begin{tabular}{|c|c|c|c|c|c|c|c|}
\hline \multirow[b]{3}{*}{ Importance } & \multicolumn{2}{|c|}{$\begin{array}{l}\text { Highly able students } \\
\qquad(n=29)\end{array}$} & \multicolumn{2}{|c|}{$\begin{array}{c}\text { Non highly able } \\
\text { students } \\
(n=132)\end{array}$} & \multirow[b]{2}{*}{$F$} & \multirow[b]{2}{*}{$p$} & \multirow[b]{2}{*}{$\eta^{2}$} \\
\hline & $M$ & $S D$ & $M$ & $S D$ & & & \\
\hline & 3.23 & .37 & 2.77 & .49 & 13.894 & .000 & .066 \\
\hline Achievability & 1.99 & .39 & 2.55 & .52 & 26.198 & .000 & .117 \\
\hline
\end{tabular}

Note. $M=$ mean; $S D=$ standard deviation.

The means for each student category are also plotted in Figure 1.

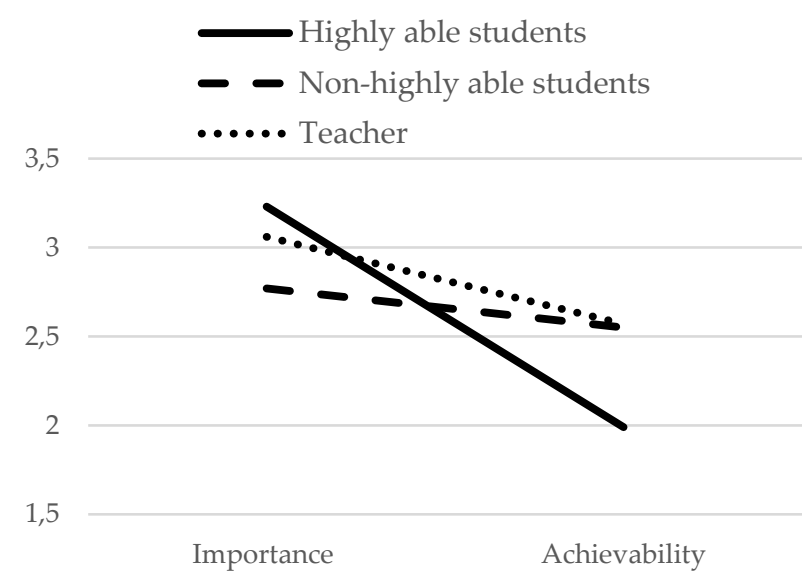

Figure 1. Teacher and Student Ratings of the Importance and Achievability of Curriculum Differentiation to Extend HAS: A Comparison of Means for the Three Categories of Respondents

The results of the ANOVA suggested that there are significant differences in the participants' perceptions of the importance of differentiated instruction, across the two groups of student respondents, $\mathrm{F}(1,198)=13.894, \mathrm{p}<.001$, partial $\eta 2=.066$, as well as the participants' perceptions of the achievability of differentiated instruction across the two groups of respondents, $F(1,198)=26.198$, 
$\mathrm{p}<.001$, partial $\eta 2=.117$. When the respondents were split by gender, this was not found to result in significant differences in the participants' perceptions of the importance of differentiated instruction, $\mathrm{F}(1,198)=1.130, \mathrm{p}=.289$, partial $\eta 2=.006$, nor was the achievability of differentiated instruction, $\mathrm{F}(1,198)=1.879, \mathrm{p}=.172$, partial $\eta 2=.009$. As mentioned, the gender of the participants is not discussed. The age of the teacher participants is also not discussed.

Planned contrasts using Bonferroni's test $(\alpha=.025)$ were used to further explore the differences between the HAS and the NHAS. HAS reported significantly higher perceived levels of importance of differentiated instruction (mean difference $=.47, \mathrm{p}<.001$ ) when compared to NHAS. With regard to achievability, the NHAS reported higher levels of perceived achievability of differentiated instruction compared to HAS (mean difference $=.55, \mathrm{p}<.001$ ).

A second ANOVA was conducted to examine differences in the NHAS ( $n=132), \operatorname{HAS}(n=29)$, and teachers $(n=43)$ on their perceived importance and perceived achievability of differentiated instruction. The respondents were divided into three groups, and the means, standard deviations, and $\mathrm{F}$ ratios for each category of respondent are displayed in Table 3. The means for each category are plotted in Figure 1.

Table 3. A Comparison of Means for the Three Categories of Respondents

\begin{tabular}{|c|c|c|c|c|c|c|c|c|}
\hline & \multicolumn{2}{|c|}{$\begin{array}{l}\text { Highly able students } \\
\qquad(n=29)\end{array}$} & \multicolumn{2}{|c|}{$\begin{array}{l}\text { Non-highly able students } \\
\qquad(n=132)\end{array}$} & \multicolumn{2}{|c|}{$\begin{array}{l}\text { Teacher } \\
(n=43)\end{array}$} & \multirow[b]{2}{*}{$F$} & \multirow[b]{2}{*}{$\mathrm{p}$} \\
\hline & $\mathbf{M}$ & SD & $\mathbf{M}$ & SD & $\mathbf{M}$ & SD & & \\
\hline Importance & 3.23 & .37 & 2.77 & .49 & 3.06 & .43 & 15.554 & .000 \\
\hline Achievability & 1.99 & .40 & 2.55 & .52 & 2.57 & .48 & 15.859 & .000 \\
\hline
\end{tabular}

Note. $M=$ mean; $S D=$ standard deviation.

The results in Table 5 suggested that there are significant differences between teachers, HAS and NHAS in their perceptions of the importance of differentiated instruction, $F(2,203)=15.554, p<$ .001 , and the achievability of differentiated instruction, $\mathrm{F}(2,203)=15.859, \mathrm{p}<.001$. To explore these differences further, an investigation into the differences between the three groups was undertaken. Planned contrasts using Bonferroni's test $(\alpha=.025)$ were used to explore the differences between the three groups.

HAS reported significantly higher perceived levels of importance of differentiated instruction compared to NHAS (mean difference $=.46, \mathrm{p}<.001$ ). Although not significant, HAS reported higher perceived levels of importance of differentiated instruction compared to teachers (mean difference $=.17, \mathrm{p}=.356$ ). Teachers also reported significantly higher perceived levels of importance of differentiated instruction compared to NHAS (mean difference $=.29, \mathrm{p}<.001$ ). With regard to achievability, the teachers reported significantly higher levels of perceived achievability of differentiated instruction compared to HAS (mean difference $=.58, \mathrm{p}<.001$ ), and although not significant, higher perceived achievability of differentiated instruction compared to NHAS (mean difference $=.02$ ). The NHAS reported significantly higher levels of perceived achievability of differentiated instruction compared to HAS (mean difference $=.55, \mathrm{p}<.001$ ). 


\section{Discussion}

As mentioned, it was important in this research to statistically compare differences between teachers', HAS', and NHAS' perceptions of HAS' extension learning. Hence ANOVA analyses were used to compare the means between the groups. As shown in Results, it was determined that some of these means were statistically significantly different to each other. Two ANOVA were conducted separately for the conceptions of learning (CoL) survey (Bowles \& Hattie, 2016) and the Kanevsky (2011) survey. To find out where the specific differences were, a Bonferroni post-hoc comparison was conducted. It is important to note that the important differences were, that while teachers generally understood how important extension learning was to HAS, according to HAS teachers were not providing several of the strategies adequately in class for HAS. The capacity of CD to provide adequate extension in secondary, mixed-ability classes is questioned.

As noted, it is clear that gifted underachievement is increasing in Australia (Buckingam, 2016; Masters, 2015). Sellar and Lingard (2013) supported the idea that gifted underachievement is a growing concern for Australia as we try to compete with our international neighbours. Underachievement and disengagement for HAS are likely to be closely linked (Feldhusen \& Kroll, 1991; HertbergDavis, 2009; Masters, 2015; Reis \& McCoach, 2000; Rimm, 1987; Shaw \& McCuen, 1960). Disengagement is likely to be closely linked to lack of appropriate extension for HAS.

This research aimed to look for potential causes within the classroom underlying this problem. Kulik (1993) explained a cause linked to this the results of this research: "The achievement level of such students falls dramatically when they are required to do routine work at a routine pace" (p. 3). However, others argue that, given diminishing resources, students of low learning ability should be the priority. This idea would support that there should be no place for wasting resources on students of already high ability. CD is not a guaranteed solution for HAS. Hertberg-Davis' (2009) judgement regarding putting in place extension for HAS is clear: "the practice of differentiation in regular classrooms has, in practice, been largely unsuccessful" (p. 251). Therefore, CD's capacity to extend HAS in mixed-ability secondary classes needs to be much more closely examined. This is highlighted by the fact that many schools claim that CD is their priority extension program.

As previously noted, correct identification of HAS is a continuing challenge within education (Renzulli, 1990; McAlpine \& Reid, 1996; Assouline, 2003; Heller, 2005; Bracken \& Brown, 2006). Being able to identify these students is a critical first step to providing CD that minimises underachievement (Piirto, 1992). Heller (2005) noted that adequate identification of HAS avoides potential conflict and under-provision of extension for these students. This current research required teachers to identify HAS from among the rest of the class using a checklist (see Table 2). The limitations of using a checklist like this are discussed later in this paper.

Some researchers believe that the use of IQ testing is critical to measuring giftedness. For example, Shaw and McCuen (1964) recommended that gifted underachievers are those whose intellectual abilities (IQ) place them above the 75th percentile of their class, while their school achievements were below the class average. However, Ziegler, Ziegler, and Stroeger (2012) argued convincingly 
that IQ is not an important factor compared to examining students' previous achievements and competencies. Goodlad (1966) supported this concept: "too often, schools reward only that which is easily measured. And what is easily measured may be inconsequential in the conduct of human affairs" (p. 17). The HAS Selection Characteristics Checklist (Table 2), despite its limitations, reflected measurable cognitive criteria as well as a broad range of observable achievements.

According to Tieso (2003): "If students are to realize true gains in achievement, not subject to the educational winds of politics, then school personnel must be aggressive in their use of appropriate and flexible ability grouping combined with curricular adjustment" (p. 35). The important words here are "appropriate and flexible ability grouping combined with curricular adjustment". It would seem that, while the removal of HAS from a mixed-ability classroom is politically mandated by some education leaders at some times, it is not always fully provided for. Borland (1993) expressed it succinctly: "The students who should be in gifted programs are those whose mental abilities are advanced to the degree that the regular school program simply does not meet their needs; anything else is politics" (p. 12).

It is widely known that $\mathrm{CD}$ aims to provide students, including HAS, with the opportunity to move academically forward at their own speed, standard, and style. However, from this study's data, it would appear that this goal is not assured in all mixed-ability classrooms. Perhaps realizations must be made that HAS' need for challenge, self-direction, and higher-level learning, may need something beyond teachers relying purely on their own attempts to differentiate the curriculum.

The impact on the field of examining evidence of what is happening, is supported by White et al. (2018) who explained that empirical evidence is rare that investigates 'school-factors' affecting gifted underachievement. Their comprehensive study on gifted-underachievement examined nine articles (from an initial 957). Results clearly showed that: "Fewer reviewed articles focused on school-related factors of gifted underachievement" (p.55).

For this current research, the role of CD to extend HAS in mixed-ability classrooms was chosen as an extremely significant school-related factor. In addition, an area of further validation for the impact provided in this study, comes from the fact that NHAS were used. They provided a control group. Ziegler and Raul (2000) complained that in their review of all empirically based articles on giftedness and talent, submitted to important journals in the years 1997 and 1998, only 20 (20\%) used a control group. Similarly supported as an important element of research design by White et al. (2018), the data provided by the NHAS group in this research, confirmed differences in perception of how successfully HAS feel they are being extended in mixed-ability secondary classes.

Asking the students how to best provide for their own individual needs, as done in this study, may be a contentious strategy for some educators. However, Long (1996) was adamant that differentiating curriculum for any student, and especially for HAS, without seeking student input, is unacceptable. She cites Traxler (1987), who stated that such an omission approaches the "magnitude of immorality" (p. 91).

However, defining exactly how to assist these students is not easily determined. Neither is the real 
size of the problem. Researchers, such as Colangelo, Kerr, Christensen, and Maxey (2004), estimated the level of gifted underachievers to be $10 \%$. Rimm (1987) calculated the level of underachievement for gifted students may, in fact, be as high as $50 \%$. The fact that this issue has not been clarified indicates that further empirical research is required.

This study's evidence that HAS do not believe that CD strategies are being achieved to extend them, may be revealing a hidden truth, which has impact within the field of gifted education. This research demonstrated that HAS perceived their extension needs were not being met by teachers attempting to differentiate the curriculum in their mixed-ability, secondary science classrooms.

Data indicated that the importance and achievability of CD were negatively correlated for the HAS. These data indicated that the greater the importance of specific curriculum differentiation strategies, the less achievable (or provided) it was, from their perspective. Teachers' survey results showed that the importance and achievability of CD were positively correlated (Figure 1). They believed that the HAS perceived extension was happening at a much higher level than did the HAS. It is this misunderstanding that must be revealed and investigated by research, and solved if possible.

In addition, indicated within the data was that NHAS valued extension to be of less importance to HAS, than did the HAS group (Figure 1). Significantly, the majority of HAS surveyed believed that extension strategies were happening far less achievably in their mixed-ability classroom for HAS, than did the NHAS. That teachers' and NHAS' results were similarly aligned could be affecting gifted underachievement in mixed-ability classes. Considering that NHAS were generally in agreement with teacher perceptions about CD achievability to extend HAS, this may provide a potential reason that teaching strategies on this topic may often aim toward the level of NHAS. Possibly, teaching 'to the middle' itself is encouraged by the fact that NHAS constitute the very large majority of a mixed-ability class. Teaching 'to the middle' might have serious disconnections for the learning goals and understandings of HAS, perhaps contributing significantly to their underachievement.

Differences between the HAS' and NHAS' states of mind during extension activities have been previously identified and compared (Kanevsky, 2011; Ireland \& Bowles, 2019). It would appear there is a great deal of distance between the views of the two student groups. Reassuringly, teachers and HAS were united in their perceptions of the importance of CD strategies to extend HAS. As mentioned, however, HAS perceived extension was being far less achieved compared to their teachers.

All the strategies mentioned in the survey are considered of real importance in gifted education (Benny \& Blonder, 2016; Van Tassel-Baska et al., 1998). Being able to work with similarly capable students, or experts suitable for their capability, or being able to work in special extension programs, were options supported far more by HAS than by teachers. Access to these options is clearly significant to HAS. Important questions are therefore raised regarding secondary schools primarily relying on $\mathrm{CD}$ to extend their HAS.

HAS in this study clearly expressed their belief that extension activities for themselves were very 
important, but, as indicated, not necessarily being provided. For example, a large majority of the HAS surveyed in this study, perceived that being allowed to work with fellow students who think like them, and who are at their own academic level, was either only occasionally happening, or not happening at all. In contrast, almost all the teachers surveyed perceived this strategy as happening usually, or always.

One of the reasons the research in this paper has impact on the field, is because it provides evidence that teachers need much stronger educational support regarding gifted education. Another is that specific extension strategies perceived by HAS to be less achieved than by teachers and NHAS, need to be closely examined. These data point to the fact that teachers need to be better informed, in order to to make the changes that are necessary. Educational clarity, as well as research regarding the increasing level of HAS' disengagement and under-achievement, need to direct these changes.

Clearly, data in this research strongly supported the importance of most of CD extension strategies. An example of further extension similar to the options provided in this survey was suggested by DeHaan (2009). He contends that extension learning options within CD can often be part of an inquiry-based style of learning. Problem-based learning activities as part of a science curriculum structure, are recommended by Van Tassel Baska et al. (1998). Newhouse-Maiden and Washbourne (1991) also argued that these strategies build a "spirit of scientific inquiry through developing laboratory skills, thinking skills and introducing a contract system that was the embodiment of research study preparation and scientific procedure" (p. 31). The availability of such strategies for HAS in mixed-ability classrooms needs to be examined.

Kulik (1993) and Beverly (1989) proposed that curriculum compacting, self-instructional programs, learning contracts, and advanced resources would be a necessary part of CD for HAS. Hockett (2009) stated that to differentiate a program for advanced science learners, the curriculum should be integrative and conceptual. Obviously, being able to provide an adequately advanced curriculum for HAS would be an essential element of differentiating their learning. However, the need for these students to be autonomous learners would possibly exceed the level of differentiation that mainstream classroom environments might currently offer.

Hockett (2009) made a strong case that a science curriculum, differentiated to address the needs of gifted students, must have an advanced level of understanding involving: abstraction; depth; breadth; and complexity. These aspects can be particularly seen in this research's survey questions. For example, participants were asked to evaluate the concept that classroom activities should be about more complicated ideas for HAS. Gallagher (2006) and Rogers (2007) noted that varying types of assessment are required to assist students to better understand their learning, as well as to facilitate feedback. These ideas correlate with participants being asked to evaluate such concepts as highly able students should be given divergent thinking activities that are different, and unusual. These concepts were strongly supported by HAS in the data.

$\mathrm{CD}$ is undoubtedly a broad and extremely complex part of pedagogy. It can be better achieved if gifted education is embedded across the school, rather than only within the confines of the classroom. For example, particular schools provide 'like ability' and extension learning environments. 
Other schools build mentoring options into their science, or other domains' curricula. In addition, some schools have teacher volunteers to provide opportunities that differentiate the learning environment for their students. In Australia, they might access volunteer programs, such as the Royal Melbourne Institute of Technology's Peer Tutor Program, or the Monash University Education Engineering Initiative. These programs offer the services of their tertiary students as science and engineering mentors within secondary schools.

Such programs focus on rigorous, open-ended, and self-directed tasks that explore relevant and complex real-world issues. These strategies were shown to be valued within the HAS results in this research. These tertiary options provide learning environments for HAS that often a teacher in a mixed-ability science classroom cannot. Without school-wide access to extension programs, CD falls into the lap of the teacher in the classroom. Teachers without gifted education training may not be aware of these resources. As mentioned, pedagogic clarity and examination of relevant data regarding increasing $\mathrm{HAS}^{\prime}$ disengagement and under-achievement, need to guide the provision of extension for HAS.

The most common message coming from empirical research about gifted underachievement, is that more authentic empirical research is needed. Dai, Swanson, and Cheng (2011) surveyed 1,234 empirical studies, and noted an enormous gap between gifted education theory and practice. In particular, Dai et al. (2011) explained that there was a gap between what educators believe, and what is being achieved. Jolly and Kettler (2008) explained this as a disconnect between priorities and reality. Data collected in this current research paper focused on a similar disconnect.

Dettmer, Landrum, and Miller (2006) noted that whole-school perspectives toward gifted education change more easily when gains and positive outcomes occur. Improved academic outcomes may be achieved by HAS who are more engaged in their learning. This may reduce HAS underachievement and also improve a school's status. However, Australia's HAS continue to underachieve despite government financial support (Browne \& Cook, 2016). Therefore, extension strategies perceived by HAS as less achieved than the teachers and the NHAS perceived, need to be further examined. Information from HAS regarding what extension is working, and what isn't, is critical to look at before any programs can be put in place.

\section{Limitations}

1. The study employed purposive sampling to examine responses from a subset of HAS, within the larger survey sample. Researchers have estimated the number of HAS in a mixed-ability group, to be at least 1 or 2 students per class (Benny \& Blonder, 2016), or approximately 10\% (Gagné, 2003). Consequently, a smaller sample of HAS is used compared to the NHAS group. The sample size of HAS in this research was small by standard procedures, traditionally used to achieve statistical adequacy (Guilford, 1954; Kline, 1986). Considering this, additional research using a larger sample of HAS from many more secondary schools is required. Similarly, a larger numbers of schools and teachers would benefit further research.

2. The HAS Selection Checklist (Table 2) used 20 characteristics suggested by Gagné (2003); Munro (2003); and Szabos (1982). A checklist such as this was used for the following reasons: 
a) Teachers were able to choose students in a timely manner.

b) It was chosen a tool that would allow teachers with limited training in gifted education to use.

c) It included characteristics that were academic (such as: 'Student is in the top 10\% of the science class academically'). It also included other characteristics that were broader observations of cognitive talent, such as: 'Has an inquisitive nature, asks good questions'.

3. In future research, this type of data would also be further validated using a wider range of HAS identification tools. These tools have been discussed by researchers, including: Renzulli (1990); McAlpine and Reid (1996); Assouline (2003); Heller (2005); and Bracken and Brown (2006). If more time is allocated within the collection of data phase, a range of informal identification procedures may also be used. These include: portfolios; information from the student or their families; and information from other educators or professionals.

4. This research focused purely on junior, secondary science classes. This was important to a) limit the variables being used within this study; and $b$ ) to focus on secondary level schooling rather than primary. As mentioned, secondary school research is more limited for secondary than for primary school research (Gentry \& Gable, 2001). In further research, applying the same questions as in Table 1 to other subject/domain areas, and establishing their relevance separately beyond this study, would advance the research. Patterns relevant to specific subjects/domains might become apparent.

\section{Conclusion}

CD that extends HAS is an area of significant practical challenge, particularly for secondary teachers in mixed-ability classrooms. HAS, in this study, showed they did not perceive that extension strategies were happening at the same levels as did their teachers. More data involving student perceptions is required, for schools to be able to address these needs. In addition, radical, and wideranging whole-school programs that enhance the wider HAS learning environment are required.

This research has brought to light that, while CD is an excellent pedagogical model, it may not be effectively providing extension for HAS in mixed-ability secondary science classrooms. It has also highlighted, however, the high level of importance HAS and teachers place on CD strategies. Teachers are undoubtedly trying to provide extension for HAS through CD. However, HAS are looking for challenge and rigour at their own levels, and in ways that teachers may be struggling to provide in the stressful arena that is a secondary, mixed-ability classroom.

This study has not indicated that teachers are not working as hard as they can to achieve extension for HAS through CD. It would appear, however, that teachers urgently need to reflect more carefully on how effective their attempts to extend HAS are perceived by HAS. Clearly, if CD alone is not providing adequately for HAS, all schools must provide a wide range of gifted education programs, beyond the classroom. As mentioned, this includes that access to mentors, relevant experts and acceleration is essential, as is the opportunity to work within a group of like minds. This paper also supports the urgent need for a diverse range of teacher extension education. Whole-school 
gifted programming should be mandatory. Australian educators need to consider this paper's evidence carefully. If schools can only provide HAS a diet of CD in mixed-ability classrooms, provided by teachers with limited or no gifted education training, underachievement and disengagement for HAS will continue to increase.

Clearly, comparing teachers' and students' perceptions of extension for HAS, provided evidence of problem areas within current pedagogy. Ongoing research is needed in this important education area, in order to support teaching and learning for HAS. The capacity of CD to extend students of high ability in mixed-ability secondary classrooms is significantly questioned by this study, and by the research of others.

\section{References}

Australian Curriculum Assessment and Reporting Authority, (2011). Retrieved June 10, 2018, from https://www.australiancurriculum.edu.au/resources/student-diversity/gifted-andtalented-students/

Archambault, F. X., Jr., Westberg, K. L., \& Brown, S. (1993). Regular classroom practices with gifted students: Results of a national survey of classroom teachers. (Research Monograph No.931020). Storrs, CT: National Research Center on the Gifted and Talented, University of Connecticut.

Assouline, S. G. (2003). Psychological and educational assessment of gifted children. In N. Colangelo \& G. Davis (Eds.), Handbook of gifted education (3rd ed., pp. 124-145). Boston, MA: Allyn \& Bacon.

Bailey, S. (2010). Reflections of a backseat driver. Vision, 2, 2-8.

Berger, S. L. (1991). Differentiating curriculum for gifted students. Retrieved from June 10, 2018, from the ERIC Digest \#E510.

Benny, N., \& Blonder, R. (2016). Factors that promote/inhibit teaching gifted students in a regular class: Results from a professional development program for chemistry teachers. Education Research International. Article ID 2742905. doi: 10.1155/2016/2742 905

Beverly, P. N. (1989). Gifted students in regular classrooms. Massachusetts: Allyn \& Bacon.

Bowles, T., \& Hattie, J. (2016). Seven motivating conceptions of learning of tertiary students. International Journal of Learning, Teaching and Educational Research, 15(3), 173-190.

Borland, J. H. (1993). Giftedness and 'The new philosophy of science'. Understanding Our Gifted, $5(6), 11-14$.

Bracken, B. A., \& Brown, E. F. (2006). Behavioral identification and assessment of gifted and talented students. Journal of Psychoeducational Assessment, 24(2), 112-122.

Browne, R. \& Cook, H. (2016). 2016 NAPLAN results not good enough, says federal education minister Simon Birmingham. The Age (2016, August 3). Retrieved from: http://www.theage.com.au.ezp.lib.unimelb.edu.au/victoria/2016-naplan-results-not-goodenough-says-federal-education-minister-simon-birmingham-20160802-gqjd8e.html

Buckingham, J. (2016) Why Australia's PISA results are a catastrophe. Financial Review. Opinion. Retrieved from: https://www.afr.com/news/economy/why-australias-pisa-results-are-acatastrophe-20161206-gt536q

Colangelo, N., Assouline, S. G., \& Gross, M. U. M. (2004). A Nation Deceived: How schools hold back America's brightest students. Iowa City: University of Iowa.

Colangelo, N., Kerr, B., Christensen, P., \& Maxey, J. (2004). A comparison of gifted underachievers and gifted high achievers. In S. Moon (Ed.), Sociallemotional issues, underachievement, and counseling of gifted and talented students (pp. 119-132). Thousand Oaks, CA: Corwin Press. 
Coleman, L. J., \& Cross, T. L. (1992). Gifted high school students' advice to science teachers. Gifted Child Today, 15, 25-26.

Cronbach, L. J. (1951). Coefficient alpha and the internal structure of tests. Psychometrika, 16(3), 297334.

Dai, D., Swanson, J., \& Cheng, H. (2011). State of research on giftedness and gifted education: A survey of empirical studies published during 1998-2010. Gifted Child Quarterly, 55, 126-138.

Davis, G., \& Rimm, S. (2004) Education of the gifted and talented (5th ed.). Boston, MA: Allyn and Bacon.

Dettmer, P. A., Landrum, M. S., \& Miller, T. N. (2006). Professional development for the education of secondary gifted students. In F. A. Dixon \& S. M. Moon (Eds.), The handbook of secondary gifted education (pp. 611-648). Waco, TX: Prufrock Press.

DeHaan, R. L. (2009). Teaching creativity and inventive problem solving in science. CBE-Life Sciences Education, 8, 172-181.

Dixon, F. A. (2006). Critical thinking: A foundation for challenging content. In F.A. Dixon \& S.M. Moon, The handbook of secondary gifted education (pp. 323-341). Waco, TX: Prufrock Press.

Emerick, L. J. (1992). Academic underachievement among the gifted: Students' perceptions of factors that reverse the pattern. Gifted Child Quarterly, 36, 140-146.

Feldhusen, J. F., \& Kroll, M. D. (1991). Boredom or challenge for the academically talented in school. Gifted Education International, 7, 80-81.

Fuller, F., \& Brown, O. (1975). Becoming a teacher. In K Ryan (Ed.), Teacher education. 74th yearbook of the national society for the study of education (pp. 25-52). Chicago: University of Chicago Press.

Gallagher, S. (2006). Guiding gifted students toward science expertise. In F. A. Dixon \& S. M. Moon (Eds.), The handbook of secondary gifted education (pp. 427-460). Waco, TX: Prufrock Press

Gagné, F. (2003). Transforming gifts into talents: The DMGT as a developmental theory. In N. Colangelo \& G. A. Davis (Eds.), Handbook of gifted education (3rd ed., pp. 60-74). Boston, Mass: Allyn \& Bacon.

Gagné, F. (2008, April). Building gifts into talents: In Brief overview of the DMGT2.0. Retrieved June 10, 2018. from: https://indooroopillyss.eq.edu.au/Supportandresources/Formsanddocuments/Documents /policy-gifted-talented-2015.pdf

Geake, J. G., \& Gross, M. U. M. (2008). Teachers' negative affect toward academically gifted students: An evolutionary psychological study. Gifted Child Quarterly, 52(3), 217-231.

Gentry, M. (2009). Myth 11: A comprehensive continuum of gifted education and talent development services. Gifted Child Quarterly, 53(4), 262-265.

Gentry, M., \& Gable, R. K. (2001). My class activities: A survey instrument to assess students' perceptions of interest, challenge, choice and enjoyment in their classrooms. Mansfield Center, CT: Creative Learning Press.

Goodlad, J. L. (1966). School, curriculum, and the individual. Waltham, MA: Blaisdell.

Guilford, J. P. (1954). Psychometric Methods. New York, NY: McGraw-Hill.

Heller, K. (2005). The Munich model of giftedness designed to identify and promote gifted students. In R. J. Sternberg \& J. E. Davidson (Eds.), Conceptions of giftedness (2nd ed., pp.147170). NewYork: Cambridge University Press.

Hertberg-Davis, H. (2009). Myth 7: Differentiation in the regular classroom is equivalent to gifted programs and is sufficient? Do classroom teachers have the time, the skill, and the will to differentiate adequately? Gifted Child Quarterly, 53, 251-253. doi: 10.1177/0016986209346927

Hockett, J. A. (2009). Curriculum for highly able learners that conforms to general education and gifted education quality indicators. Journal for the Education of the Gifted, 32(3), 394-440. 
Hollingsworth, S. (1989). Prior beliefs and cognitive change in learning to teach. American Educational Research Journal, 26, 160-189.

Ireland, C., \& Bowles, T. (2019). Increasing unrealized potential of Australian gifted secondary students. (Manuscript in preparation).

Jolly, J. L., \& Kettler, T. (2008). Gifted education research 1994-2003 A disconnect between priorities and practice. Journal for the Education of the Gifted, 31, 427-446.

Kanevsky, L. (2011). Deferential differentiation: What types of differentiation do students want? Gifted Child Quarterly, 55(4), 279-299.

Kline, P. (1986). A handbook of test construction. New York, NY: Methuen.

Kulik, J. (1993). An analysis of the research on ability grouping. National Research Center on the Gifted and Talented, Storrs, CT. 8-9. Retrieved July 20, 2018, from:

https://nrcgt.uconn.edu/research-based_resources/kulik/

Lamb, T. E. (2004). Learning independently? Pedagogical and methodological implications of new learning environments. In Proceedings of the Independent Learning Conference 2003 (pp. 1-9).

Lassig, C. J. (2009a). Promoting creativity in education : from policy to practice: An Australian perspective. In Proceedings of the 7th ACM Conference on Creativity and Cognition: Everyday Creativity (pp. 229-238). Berkeley, CA: The Association for Computing Machinery, University of California.

Lassig, J. (2009b) Teachers' attitudes towards the gifted : the importance of professional development and school culture. Australasian Journal of Gifted Education, 18(2), 32-42.

Long, P. (1996). Student views of differentiated education for ability differences. In W. Vialle \& J. Geake, J. (Eds.), The gifted enigma, a collection of articles, 2002 (pp. 279-293). Highett, Vic.: Hawker Brownlow Education.

Maker, C. J. (1982). Curriculum development for the gifted. Rockville, MD: Aspen.

Masters, G. (2015). Challenging our most able students. Teacher Magazine. Retrieved June 23, 2018. from https://www.teachermagazine.com.au/geoff-masters/.../challenging-our-most ablestudents

Mastropieri, M. A., \& Scruggs, T. E. (2004). The inclusive classroom: strategies for effective instruction (2nd ed.). Columbus, OH: Prentice Hall.

McAlpine, D., \& Reid, N. A. (1996). Teacher Observation Scales for Identifying Children with Special Abilities: Teachers' Handbook. Educational Research and Development Centre, Massey University.

Munro, J. (2003, June). How people learn'. In Keynote presentation at the Biennial Curriculum Corporation Conference How to Teach Better (Vol. 12, pp. 243-54).

Newhouse-Maiden, L., \& Washbourne, M. (1991). Experiences in gifted education: Implications for teaching strategies for a clever country. Australian Journal of Teacher Education, 16(2), 30-34.

Piirto, J. (1992). Understanding those who create. Dayton: Ohio Psychology Press.

Reis, S. M., \& Burns, D. (1991). Developing a thinking skills component in the Gifted Education Program. Roeper Review, 14, 72-79.

Reis, S. M., \& McCoach, D. B. (2000). The underachievement of gifted students: What do we know and where do we go? Gifted Child Quarterly, 44, 152-170

Renzulli, J. S. (1990). A practical system for identifying gifted and talented students. Early Child Development and Care, 63(1), 9-18.

Rimm, S. B. (1987). Why bright children underachieve: The pressures they feel. Gifted Child Today, 10, 30-36.

Rogers, K. B. (1991). The relationship of grouping practices to the education of the gifted and talented learner: Research-based decision-making series. Storrs, CT: University of Connecticut, National Research Center on the Gifted and Talented. 
Rogers, K. B (1998). Using current research to make 'good' decisions about grouping. National Association of Secondary Schools Principals Bulletin, 82(595), 38-46.

Rogers, K. B. (2007). Lessons learned about educating the gifted and talented: A synthesis of the research on educational practice. Gifted Child Quarterly, 51(4), 382-396.

Sellar, S., \& Lingard, B.( 2013). Looking east: Shanghai, PISA 2009 and the reconstitution of reference societies in the global education policy field. Comparative Education, 49, 464-485. doi: 10.1080/03050068.2013.770943

Shaw, M. C., \& McCuen, J. T. (1960). The onset of academic underachievement in bright children. Journal of Educational Psychology, 51, 103-108.

Szabos, J. (1989). Bright child, gifted learner. Challenge, 34(4), 3.

Tabachnick, B. G., \& Fidell, L. S. (2013). Using multivariate statistics (6th ed.). Boston, MA: Pearson.

Tieso, C. L. (2003). Ability grouping is not just tracking anymore. Roeper Review, 26(1), 29-36.

Tomlinson, C. A., Tomchin, E. M., Callahan, C. M., Adams, C. M., Pizzat-Tinnin, P., Cunningham, C. M., \& Imbeau, M. (1994). Practices of preservice teachers related to gifted and other academically diverse learners. Gifted Child Quarterly, 38(3), 106-114.

Tomlinson, C.A. (2003). Fulfilling the promise of the differentiated classroom: Strategies and Tools for Responsive Teaching. Alexandria, VA: Association for the Supervision of Curriculum Development.

Tomlinson, C., \& Moon, T. (2013). Assessment and student success in a differentiated classroom. Alexandria, VA: Association for the Supervision of Curriculum Development.

Tomlinson, C. (2014). The differentiated classroom: Responding to the needs of all learners (2nd ed.). Alexandria, VA: Association for the Supervision of Curriculum Development.

Traxler, M. (1987). Gifted education program evaluation: A national review. Journal for the Education of the Gifted, 10(2), 107-113.

Van Tassel-Baska, J. (1986). Effective curriculum and instructional models for talented students. Gifted Child Quarterly, 30(4), 164-169.

Van Tassel-Baska, J., Bass, G., Ries, R., Poland, D., \& Avery, L. (1998). A national study of science curriculum effectiveness with high ability students. Gifted Child Quarterly, 42(4), 200-211.

Watters, J. J., \& Diezmann, C. M. (2003). The gifted student in science: Fulfilling potential. Australian Science Teachers Journal, 49(3), 46-53.

White, S., Graham, L., \& Blaas, S. (2018).Why do we know so little about the factors associated with gifted underachievement? A systematic literature review. Educational Research Review, 24, $55-66$.

Whitmore, J. (1980) Giftedness, conflict and underachievement. Boston, MA: Allyn and Baker.

Winner, E. (1996). Gifted children: Myths and realities. New York: Basic Books.

Yang, M. (2006). A critical review of research on questioning in education: Limitations of its positivistic basis. Asia Pacific Education Review, 7(2), 195-204.

Yoon, C. H. (2009), Self-regulated learning and instructional factors in the scientific inquiry of scientifically gifted Korean middle school students. Gifted Child Quarterly, 53, 203-216.

Ziegler, A., \& Raul, T. (2000). Myth and reality: A review of empirical studies on giftedness. High Ability Studies, 11, 113-136.

Ziegler, A., Ziegler, A., \& Stoeger, H. (2012). Shortcomings of the IQ-based construct of underachievement. Roeper Review, 34, 2, 123-132. 


\section{Appendix A. STUDENT SURVEY}

\begin{tabular}{|c|c|c|c|c|c|c|c|c|c|}
\hline & Student Survey Name: & & nport & $\operatorname{tanc}$ & & Acl & hiev & abi & lity \\
\hline & $\begin{array}{l}\text { Tick two of the columns to show } \\
\text { 1. how important you think each is to extend highly able students, } \\
\text { 2. how achievable each is in a science classroom to extend highly able students. }\end{array}$ & 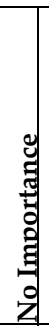 & 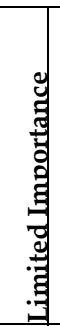 & 羍 & 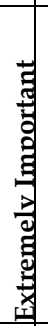 & 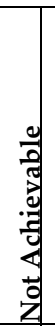 & $\begin{array}{l}0 \\
0 \\
0 \\
0 \\
0 \\
0 \\
0 \\
0 \\
0 \\
0\end{array}$ & & 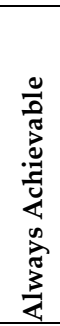 \\
\hline & Individual Learning Plans are a good idea for students of high ability & & & & & & & & \\
\hline క్ & $\begin{array}{l}\text { Harder text books (beyond Year } 7 \text { level) and other more advanced materials } \\
\text { should be provided for students of high ability. }\end{array}$ & & & & & & & & \\
\hline 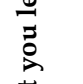 & $\begin{array}{l}\text { Classroom activities should be about more complicated ideas for highly able stu- } \\
\text { dents. }\end{array}$ & & & & & & & & \\
\hline$\underset{\frac{\pi}{3}}{\frac{\pi}{3}}$ & $\begin{array}{l}\text { Classroom activities should involve abstract thinking, (in other words, go beyond } \\
\text { the facts) for highly able students. }\end{array}$ & & & & & & & & \\
\hline 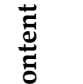 & $\begin{array}{l}\text { Classes for highly able students should focus on the main concepts and themes of } \\
\text { a topic. }\end{array}$ & & & & & & & & \\
\hline & $\begin{array}{l}\text { Content of a unit should be in part designed to take into consideration the special } \\
\text { abilities and interests of highly able learners. }\end{array}$ & & & & & & & & \\
\hline & $\begin{array}{l}\text { Highly able students should be given divergent thinking activities that are differ- } \\
\text { ent and unusual }\end{array}$ & & & & & & & & \\
\hline 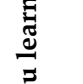 & $\begin{array}{l}\text { Highly able students should not have to do the parts of the unit that they already } \\
\text { know so they have time to do other things of their own choice in the unit }\end{array}$ & & & & & & & & \\
\hline$\overbrace{0}^{0}$ & $\begin{array}{l}\text { Highly able students should be able to work on a subject at a higher level (e.g. } \\
\text { Year } 8 \text { or } 9 \text { level) and do the assessments for that level. }\end{array}$ & & & & & & & & \\
\hline בُ & Highly able students should be able to work at their own pace at their own level. & & & & & & & & \\
\hline 怤 & $\begin{array}{l}\text { Highly able students should be able to work on activities that use higher-order } \\
\text { thinking skills, for example analysis, synthesis, and evaluation }\end{array}$ & & & & & & & & \\
\hline & $\begin{array}{l}\text { Highly able students need 'tiered' lessons (learning by steps) with different levels } \\
\text { of challenge, so that they can jump up to the level that suits them. }\end{array}$ & & & & & & & & \\
\hline & Assignments should have choices designed for highly able students. & & & & & & & & \\
\hline 岕 & $\begin{array}{l}\text { Highly able students should be able to choose, with the teacher's guidance, their } \\
\text { own ways to demonstrate what they have learned. }\end{array}$ & & & & & & & & \\
\hline 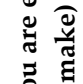 & $\begin{array}{l}\text { Highly able students should be able to work on tasks involving real world prob- } \\
\text { lems }\end{array}$ & & & & & & & & \\
\hline 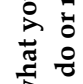 & $\begin{array}{l}\text { Highly able students should be able to present their work to be judged by real au- } \\
\text { diences (various people or groups) }\end{array}$ & & & & & & & & \\
\hline 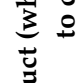 & $\begin{array}{l}\text { What is needed as assessment should be worked out at the start by the teacher and } \\
\text { the student }\end{array}$ & & & & & & & & \\
\hline$\stackrel{2}{2}$ & $\begin{array}{l}\text { Highly able students should be encouraged to suggest practical uses for what they } \\
\text { learn }\end{array}$ & & & & & & & & \\
\hline & $\begin{array}{l}\text { Highly able students should be allowed to work with students in the class who } \\
\text { think like them and are at their level. }\end{array}$ & & & & & & & & \\
\hline & $\begin{array}{l}\text { Highly able students should be allowed to work with older classes for some of the } \\
\text { time, as needed. }\end{array}$ & & & & & & & & \\
\hline$\ddot{\Xi}$ & $\begin{array}{l}\text { Highly able students should be allowed to do their own projects about things that } \\
\text { interest them, }\end{array}$ & & & & & & & & \\
\hline 疍 & $\begin{array}{l}\text { Highly able students should be encouraged to take part in competitions, extra-cur- } \\
\text { ricular programs (clubs, choir, orchestra, sport teams, art shows etc) and on-line } \\
\text { learning. }\end{array}$ & & & & & & & & \\
\hline & $\begin{array}{l}\text { Highly able students should have special tutors or mentors who are experts in } \\
\text { something the student is interested in. }\end{array}$ & & & & & & & & \\
\hline & $\begin{array}{l}\text { Highly able students should be allowed to be in special 'pull-out' programs for } \\
\text { some lessons each week in the subject they are good at. }\end{array}$ & & & & & & & & \\
\hline
\end{tabular}

Note. Adapted from Maker, 1982. 


\section{Appendix B. HIGHLY ABLE STUDENT SELECTION CHECKLIST}

\begin{tabular}{|c|c|c|c|c|c|}
\hline Highly Able Student Characteristics & $\begin{array}{c}\text { Strongly } \\
\text { agree }\end{array}$ & Agree & $\begin{array}{l}\text { Neither } \\
\text { A/D }\end{array}$ & Disagree & $\begin{array}{l}\text { Strongly } \\
\text { disagree }\end{array}$ \\
\hline $\begin{array}{l}\text { 1. Student is in the top } 10 \% \text { of the science class aca- } \\
\text { demically }\end{array}$ & & & & & \\
\hline 2. The capacity to make unusual links between ideas & & & & & \\
\hline 3. Learns at significantly faster rates & & & & & \\
\hline $\begin{array}{l}\text { 4. Manipulates abstract ideas and makes connections } \\
\text { to an advanced degree. }\end{array}$ & & & & & \\
\hline $\begin{array}{l}\text { 5. Has an extensive and detailed memory, particularly } \\
\text { in an area of interest. }\end{array}$ & & & & & \\
\hline $\begin{array}{l}\text { 6. Has vocabulary advanced for age-precocious lan- } \\
\text { guage. }\end{array}$ & & & & & \\
\hline 7. Asks intelligent questions. & & & & & \\
\hline $\begin{array}{l}\text { 8. Is able to identify the important characteristics of } \\
\text { new concepts, problems. }\end{array}$ & & & & & \\
\hline $\begin{array}{l}\text { 9. Has a broad base of knowledge - a large quantity of } \\
\text { information. }\end{array}$ & & & & & \\
\hline $\begin{array}{l}\text { 10. Uses analogical thinking, problem solving, or rea- } \\
\text { soning. }\end{array}$ & & & & & \\
\hline 11. Has an intense, sustained interest. & & & & & \\
\hline 12. Has hobbies/collections related to field. & & & & & \\
\hline $\begin{array}{l}\text { 13. Attracted toward cognitive complexity, enjoys solv- } \\
\text { ing complex problems. }\end{array}$ & & & & & \\
\hline 14. Solves problems intuitively using insight. & & & & & \\
\hline 15. Has an inquisitive nature, asks good questions. & & & & & \\
\hline 16. Understands abstract ideas and concepts. & & & & & \\
\hline 17. Reads widely in an academic field. & & & & & \\
\hline $\begin{array}{l}\text { 18. Visualizes images and translates into other forms- } \\
\text { written, spoken, symbolic-music notation, num- } \\
\text { bers, letters. }\end{array}$ & & & & & \\
\hline 19. Can reverse steps in the mental process. & & & & & \\
\hline 20. Underachieving gifted student & & & & & \\
\hline
\end{tabular}

Note. Adapted from Szabos (1982); Gagné (2003); Munro (2003). 